\title{
СТАРОРОМАШКИНСКИЙ АРХЕОЛОГИЧЕСКИЙ КОМПЛЕКС: НЕКОТОРЫЕ ИТОГИ И ПЕРСПЕКТИВЫ ИССЛЕДОВАНИЯ
}

\author{
(C) 2021 г. А.3. Нигамаев
}

Ромашкинский (Староромашкинский) археологический комплекс представляет собой остатки достаточно крупного болгарского города домонгольской эпохи. Статья посвящена результатам исследований Елабужской археологической экспедиций на памятнике начиная с 2013 года. На основе изучения выявленных объектов и материала из раскопок определено время функционирования поселения второй половиной X - первой третью XIII вв. Богатый комплекс находок показывает сложный этнокультурный состав его жителей. Интересные выводы сделаны по группам керамики населения прикамско-приуральских истоков.

Ключевые слова: археология, Волжская Болгария, домонгольский период, городище, посад, население, находки, керамика, украшения, вооружение.

\section{STAROROMASHKINO ARCHAEOLOGICAL COMPLEX: STUDY RESULTS AND PROSPECTS}

\section{A.Z. Nigamaev}

The Romashkino (Staroromashkino) archaeological complex is the remains of a fairly large Bolgar city of the pre-Mongol period. The paper presents the results of the studies by Elabuga archaeological expeditions carried out at the site since 2013. Based on the study of the identified objects and excavation material, the time of the settlement's functioning was determined as the second half of the $10^{\text {th }}-$ the first third of the $13^{\text {th }}$ centuries. The vast collection of finds demonstrates the complex ethnic-cultural composition of the population. Interesting conclusions were made about the groups of ceramics of the population of the Kama-Ural origin.

Keywords: archaeology, Volga Bolgaria, pre-Mongol period, hillfort, posad, population, finds, ceramics, jewelry, weapons.

Один из значимых памятников, расположенных на территории Закамья восточнее Джукетау, является Староромашкинский (Ромашкинский) археологический комплекс, состоящий из городища, трех прилегающих посадов и двух некрополей. Как часть данного комплекса расматривают и расположенное в 2 км юго-западнее кладбище «Ташбилге» («Ханское») с надмогильными камнями золотоордынской эпохи. Староромашкинское городище расположено в 16 км южнее Камы (19 км юго-восточнее Джукетау) и 0,5 км южнее с. Старое Ромашкино Чистопольского района Республики Татарстан (рис. 1). Комплекс является остатками довольно значительного болгарского города домонгольской эпохи, но в известных на сегодняшний день письменных источниках поселение на данном месте не упоминается. У местного населения исторического названия объекта не сохранилось, т. к. до его появления здесь не позднее 1645 г. (жители с. Старое Ромашкинопереселившиеся из-за Волги татары-мишары) эти земли некоторое время являлись «пустошью». Из-за туфлеобразной формы городища окрестное население называет его «Калюш»

(«калоша»), хотя среди татар используется и название «Кала» («крепость, город»).

Староромашкинское городище в 1925 г. исследовалось А.К. Буличем (Булич, 1926), в 1952 г. - КАЭ (Хлебникова, 1962; Фахрутдинов, 1975, с. 147, № 1137; Археологические памятники..., 1988, с. 70), в 1989 г.К.А. Руденко (Руденко, 1990). В 2008 г. на городище охранно-спасательные работы проводил Н.Г. Набиуллин. Кроме описания городища, оборонительных сооружений им был заложен небольшой раскоп у западной кромки внутренней площадки (раскоп I) (Набиуллин, 2010, с. 7).

Начиная с 2013 г., на памятнике работает Елабужская археологическая экспедиция. За этот период проведен целый ряд мер охранноспасательного и научно-исследовательского характера. Были уточнены масштабы разрушительных процессов на памятнике и определены меры по их прекращению. Бессменным научным консультантом во время работы экспедиции на памятнике был д. и. н., проф. Ф.Ш. Хузин (выражаем глубокую признательность наставнику). В 2013 г. начато укрепление наиболее разрушающегося северо-запад- 


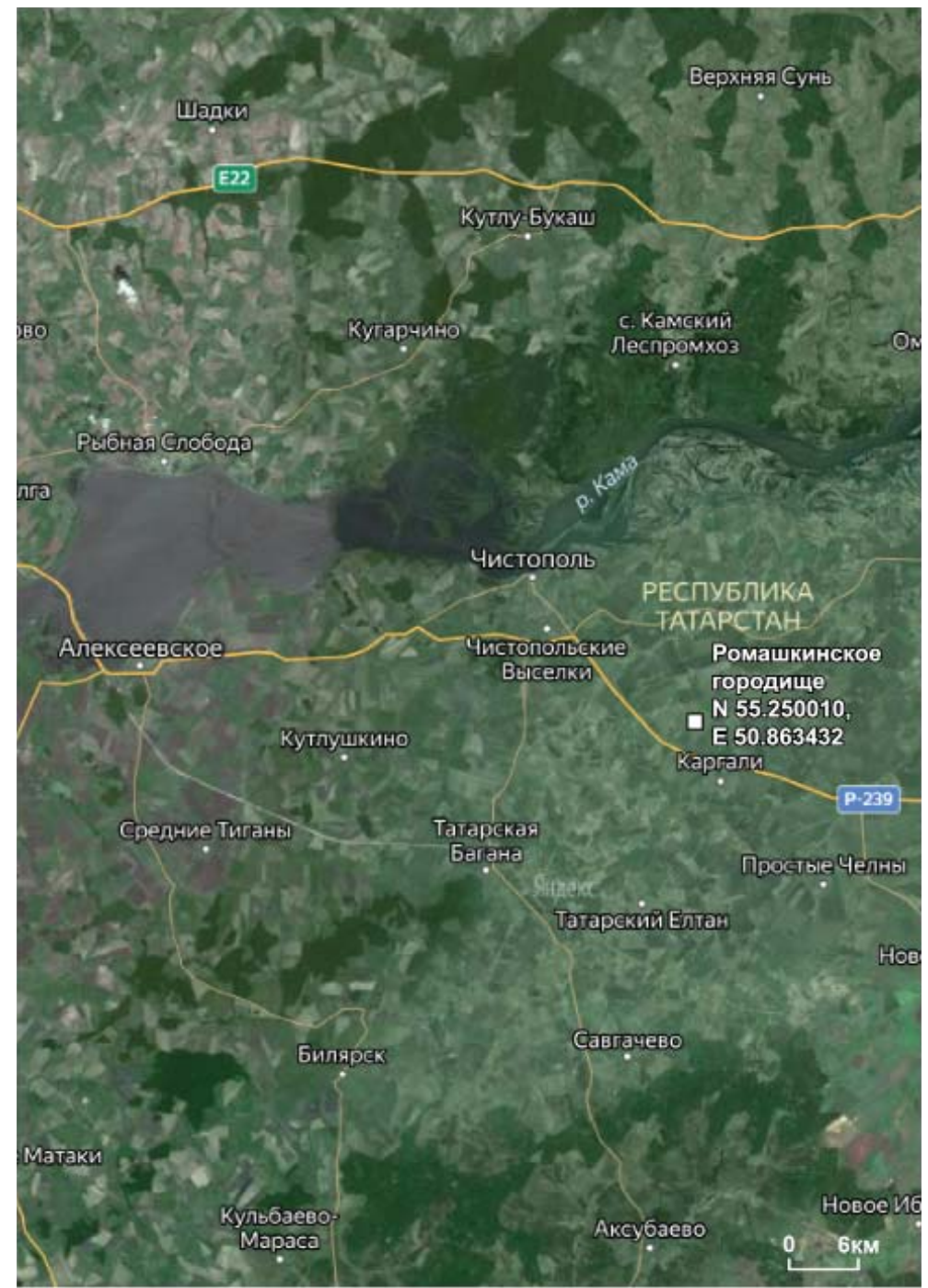

Рис. 1. Местоположение Ромашкинского городища (спутниковый снимок сервиса Яндекс.Карты)

Fig. 1. Location of Romashkino hillfort (satellite image from Yandex.Maps)

ного склона городища. Такие же работы были проведены в 2016 г. на восточном конце второго южного вала. Прекращена вспашка территории южного посада. В 2017 г. осмотрены и описаны намогильные камни золотоордынского кладбища «Ташбилге», которые выявили существенные изменения на памятнике за последнее десятилетие.

Большие работы проводились и по уточнению пределов комплекса (рис. 2). Детальный осмотр окрестностей памятника в 2016 г. подтвердил, что территория, тянущаяся от городища на юго-запад, занята обширным посадом. Причем его следы прослеживаются на 200-250 м дальше тех границ, которые указывались ранее. Кроме того, часть западного посада занята территорией современного села. В участках жителей села часты средневековые находки в виде обломков глиняной посуды и изделий из металла. За несколько столетий расширяющиеся овраги сократили площадь комплекса, значительная часть посада разрушена водами водохранилища (пруда).

В 2017 г. работы по уточнению территории комплекса были продолжены. С учетом ландшафтных особенностей памятника и многолетних распашек его поверхности сделаны детальные измерения площади распространения находок. Тогда же были уточнены размеры городища и посадов с использованием GoogleMaps. Так, площадь самого городища с укреплениями равна 39814 кв. м (3,98 га), без укреплений - 26271 кв. м (2,63 га). К слову, наиболее близкие данные были у Н.Г. Набиуллина (3,8 га).

Площадь восточного посада вместе с могильником равна 371000 кв. м (37,1 га), западного с западным могильником - 250000 кв. м (25 га), а наиболее плотно обжитого южного посада - 329021 кв. м (32, 9 га). Таким образом, общая площадь пригородных поселений с домонгольскими могильниками равна 95 га, а всего комплекса - почти 99 га. 


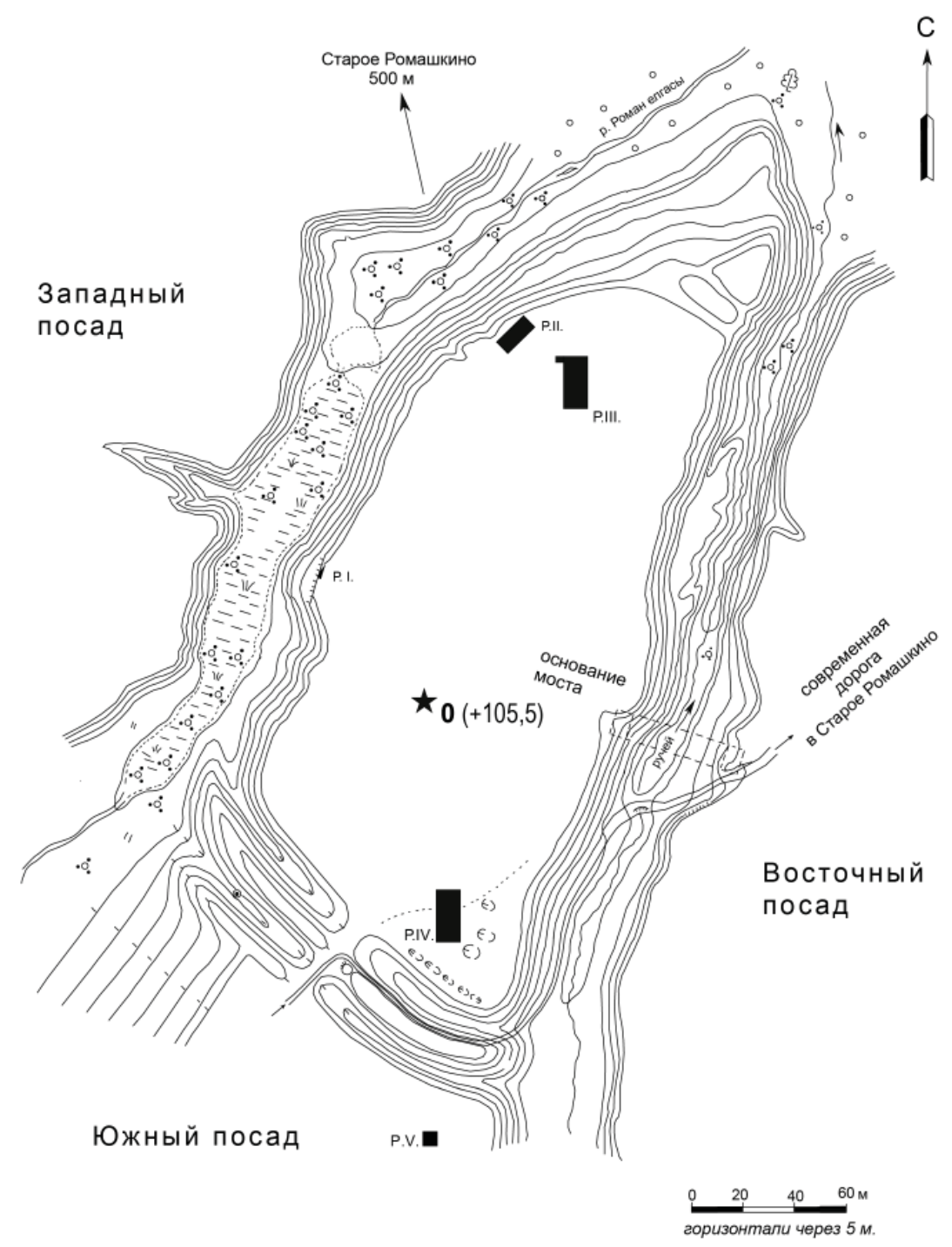

Рис. 2. План Ромашкинского городища с указанием раскопов и нулевой отметки городища (по А.З. Нигамаеву) Fig. 2. Plan of the Romashkino hillfort indicating the excavations and the reference level of the hillfort (after A.Z. Nigamaev)

Ромашкинское городище Елабужской экспедицией раскапывалось в 2013, 2016 и 2017 гг. Всего на городище ею вскрыто 648 кв. м тремя раскопами.

Раскоп II площадью 160 кв. м изучался в 2013 году. Он располагался на северо-западной части городища, вдоль укрепленного участка склона. Мощность культурного слоя вне объектов колеблется в пределах от $32 \mathrm{~cm}$ до 100 см. Его стратиграфия: плотный дерн (5-8 см), переработанный в результате вспашки в XVII-XIX вв. слой в виде рассыпчатой (местами комковой) темной гумусированной супеси с незначительными включениями камней (8-20 см), слой серой супеси с включениями угля, древесного тлена, битого известняка и глины (50-70 см), датированный второй половиной X - первой третью XIII вв., погребенная почва в виде плотного чернозема (в большей части раскопа переработана, но в восточном углу раскопа до 90 см), материк в виде буро-коричневой и коричневой глины. В пределах раскопа полностью или частично исследованы 6 ямных конструкций, из которых соор. 1, представляющее целый комплекс из сруба, каменных завалов, ям-кладовок, является остатками сгоревшего жилища.

В 2016 г. рядом был заложен раскоп III площадью 248 кв. м. В его пределах исследованы 26 ямных конструкций, одна из которых представляет собой остатки жилища. Из культурного слоя вне сооружений и заполнения ям был собран интересный комплекс средневековой гончарной и лепной керамики (28 320 фр.), а также индивидуальных находок (276 ед.). Мощность культурного слоя и его стратиграфия идентичны данным раскопа II.

Раскоп IV площадью 240 кв. м изучался в 2017 г. Он был заложен на юго-восточной части площадки городища рядом в крупными яма-разрушениями. Мощность культурного слоя раскопа вне объектов колеблется в 
пределах от 30 до 72 см (в большой части вскрытой площади его мощность 40-45 см). Основной слой, не разрушенный в результате пахоты в последующую эпоху, представлен в виде серой или серо-коричневой супеси с включениями угля, древесного тлена, известняка и глинистых вкраплений. Заметые суглинистые включения отличают его от слоя II раскопов северной части городища. В пределах раскопа выявлено и исследовано 2 "погребения" и 26 конструкций.

Жилища. За время исследований на памятнике изучено 4 жилища, относящихся к нескольким типам. Жилище № 1 (раскоп II) был выявлен в виде подпрямоугольной конструкции размерами $4 \times 3,5$ м на уровне - 57-63 см. Ориентировано углами по сторонам света. Местами сохранились в сильно обугленном состоянии бревна стен и настил из досок (пол?). Вход в конструкцию был с северо-востока. Печь в виде скопления крупных камней из песчаника и известняка, лежащих на крупном плоском песчанике размерами $103 \times 82 \times 25$ см, располагалась в юго-восточном углу жилища. К печи с северовостока примыкало крупное пятно из перекала и золы толщиной до 12 см. Под северным и южным концом плиты располагались 2 столбовые ямки диаметром 10 и 20 см. В пределах конструкции располагались 4 ямы различного назначения.

Аналогичное жилище (№ 2) было изучено в 21 м восточнее в пределах раскопа III. Печь в нем также располагается в юго-восточном углу. Но имеются и некоторые отличия:

чуть меньший размер $(3,1 \times 2,8$ м);

ориентация стенами по сторонам света; отсутствие ям-кладовок;

печь из крупных камней располагается на глиняном перекале толщиной 22-28 см.

Близкие по планировке, но несколько большие по размерам жилища изучены на юговостоке городища (раскоп IV).

Керамика. Наиболее массовым материалом на Ромашкинском археологическом комплексе являются фрагменты глиняной посуды. Всего за четыре года раскопок на памятнике было собрано 65885 фрагментов гончарной и лепной керамики. При определении принадлежности к той или иной этнокультурной группе посуды населения Волжской Болгарии использовался метод выделения групп керамики по комплексу признаков, разработанный Т.А. Хлебниковой (1984).

Таблица 1

Table 1

\begin{tabular}{|c|c|c|c|c|c|c|c|c|}
\hline & $\begin{array}{l}\text { I гр. } \\
(\%)\end{array}$ & VII гр.(\%) & VIII гр.(\%) & $\begin{array}{c}\text { XIII } \\
\text { гр.(\%) }\end{array}$ & XVII гр. (\%) & \begin{tabular}{|c|} 
XVIII гр. \\
$(\%)$
\end{tabular} & $\begin{array}{c}\text { Остальн. } \\
(\%)\end{array}$ & $\begin{array}{c}\text { Всего } \\
(\%)\end{array}$ \\
\hline Раскоп II & $\begin{array}{l}12850 \\
(87,3)\end{array}$ & $\begin{array}{l}1396 \\
(9,4)\end{array}$ & $\begin{array}{c}30 \\
(0,2)\end{array}$ & $\begin{array}{l}273 \\
(2)\end{array}$ & $\begin{array}{c}40 \\
(0,2)\end{array}$ & $\begin{array}{c}2 \\
(0,01)\end{array}$ & $119(0,81)$ & $\begin{array}{c}14710 \mathrm{\phi p} . \\
(100)\end{array}$ \\
\hline Раскоп III & $\begin{array}{l}24553 \\
(86,7)\end{array}$ & $\begin{array}{l}3166 \\
(11,3)\end{array}$ & $\begin{array}{c}18 \\
(0,06)\end{array}$ & $\begin{array}{c}295 \\
(1,04)\end{array}$ & $65(0,2)$ & - & $251(0,87)$ & $\begin{array}{c}28320 \text { фp. } \\
(100)\end{array}$ \\
\hline Раскоп IV & $\begin{array}{l}19791 \\
(91,2) \\
\end{array}$ & $\begin{array}{l}1181 \\
(5,4)\end{array}$ & $\begin{array}{c}38 \\
(0,1)\end{array}$ & $\begin{array}{c}386 \\
(1,7)\end{array}$ & $\begin{array}{c}57 \\
(0,2) \\
\end{array}$ & $\begin{array}{c}3 \\
(0,01) \\
\end{array}$ & $\begin{array}{c}226 \\
(1)\end{array}$ & $\begin{array}{c}21681 \mathrm{pp} . \\
(100)\end{array}$ \\
\hline Раскоп V & $1003(85,4)$ & $\begin{array}{c}104 \\
(8,8)\end{array}$ & $\begin{array}{c}3 \\
(0,2)\end{array}$ & $\begin{array}{c}37 \\
(3,1)\end{array}$ & $\begin{array}{c}2 \\
(0,1)\end{array}$ & - & $\begin{array}{c}25 \\
(2,1)\end{array}$ & $\begin{array}{c}1174 \text { фp. } \\
(100)\end{array}$ \\
\hline Всего & $\begin{array}{c}58197 \\
(88,29)\end{array}$ & $\begin{array}{r}5847 \\
(8,87)\end{array}$ & $\begin{array}{c}89 \\
(0,14)\end{array}$ & $\begin{array}{l}991 \\
(1,5)\end{array}$ & $\begin{array}{c}164 \\
(0,25)\end{array}$ & $\begin{array}{c}5 \\
(0,008)\end{array}$ & $\begin{array}{c}621 \\
(0,94)\end{array}$ & $\begin{array}{l}65885 \\
(100)\end{array}$ \\
\hline
\end{tabular}

Как видно из таблицы, в Староромашкино прослеживается характерное для крупных болгарских памятников явное доминирование общеболгарской (I группы) посуды. Больше представлена она в юго-восточной части городища (>91\%), а наименьшая ее доля - в посаде $(>85 \%)$. Эта круговая посуда мелкопесочного теста, преимущественно коричневого и желто-красного цвета, хорошего обжига, с характерным полосчатым или сплошным лощением и линейно-волнистым орнаментом. По форме выделяются горшки, хумы, корчаги, кувшины, кринки, а также мискообразные и чашевидные сосуды. Большинство сосудов относятся кувшинам и горшкам (рис. 3: 1-8).

В материалах раскопов присутствует лепная и подправленая на круге керамика - всего 7095 фрагментов. Из них почти $82,5 \%$ это средневековая прикамско-приуральская посуда VII группы (“постпетрогром”, по Е.П. Казакову) (рис. 3: 9, 10). Это преимущественно выделанная от руки круглодонная посуда раковинного теста с высокой горловиной, раздутым, иногда шарообразным туловом, украшенная веревочно-гребенчатым (гребенчато-шнуровым) орнаментом. Она 


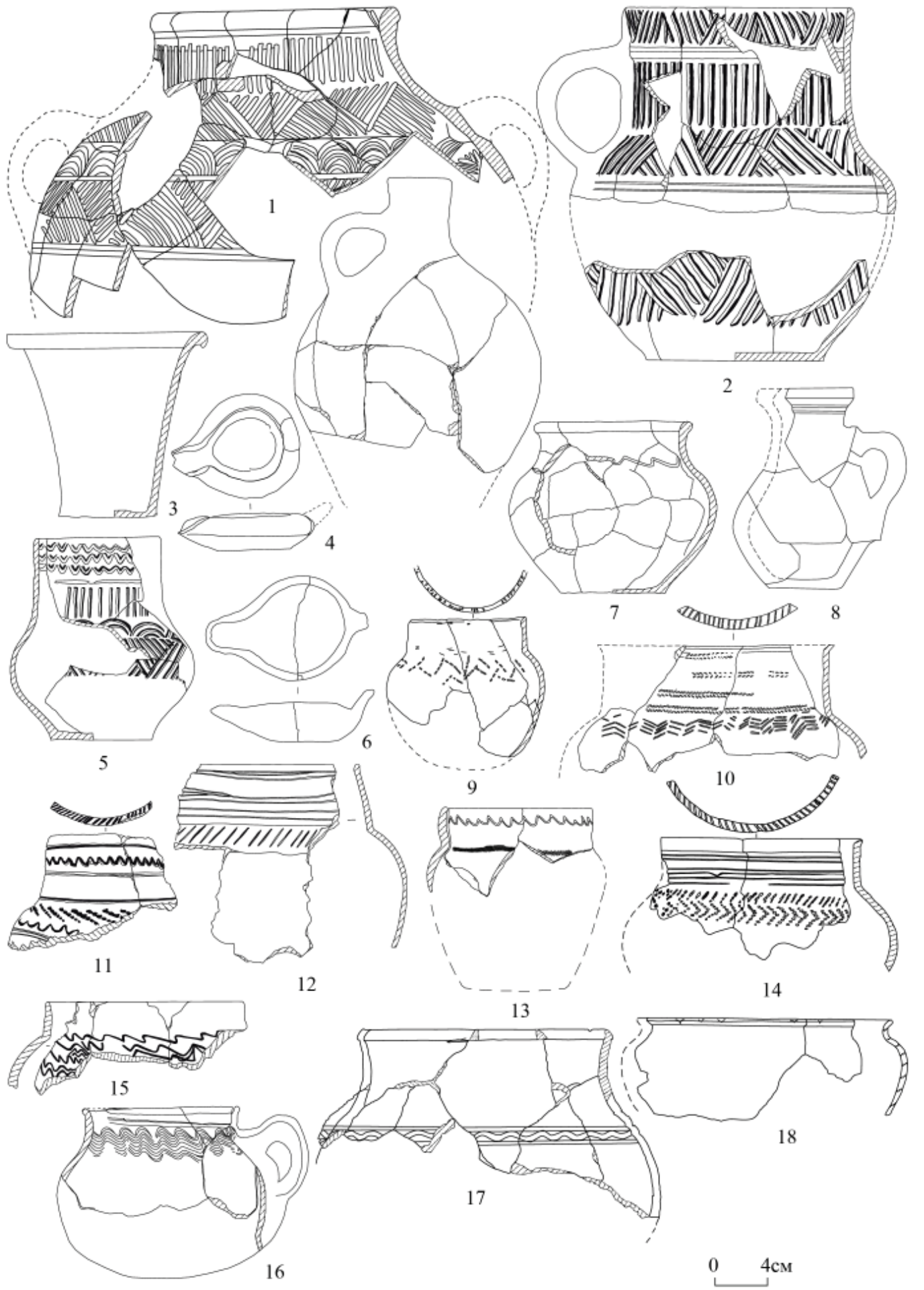

Рис. 3. Керамика из Ромашкинского городища

(9, 13, 16 - раскоп II; 1, 4-7, 17 - раскоп III; 2, 3, 8, 10-12, 14, 15, 18 - раскоп IV); (1-8 - I гр.; 9-10 - VII гр.; 11-14 - VIII гр.; 15-16 - XIII гр.; 17 - XVII гр.; 18 - XVIII гр.;)

Fig. 3. Ceramics from Romashkino hillfort

(9, 13, 16 - excavation II; 1, 4-7, 17 - excavation III; 2, 3, 8, 10-12, 14, 15, 18 - excavation IV); (1-8 - b. I; 9-10 - b. VII; 11-14 - b. VIII; 15-16 - b. XIII; 17 - b. XVII; 18 - b. XVIII;)

представлена горшками и мисками от темнокоричневого до светло-серого оттенков, хотя редко встречаются сосуды черного и бурого цветов. Можно отметить некоторые хронологические различия. Отличительная особенность ранних форм посуды: обильная примесь мелкотолченой раковины в тесте, иногда встречается тальк;

“костровой” обжиг, что дает разные оттенки разных сторон одного сосуда;

тонкостенность сосуда и прочность черепка; 

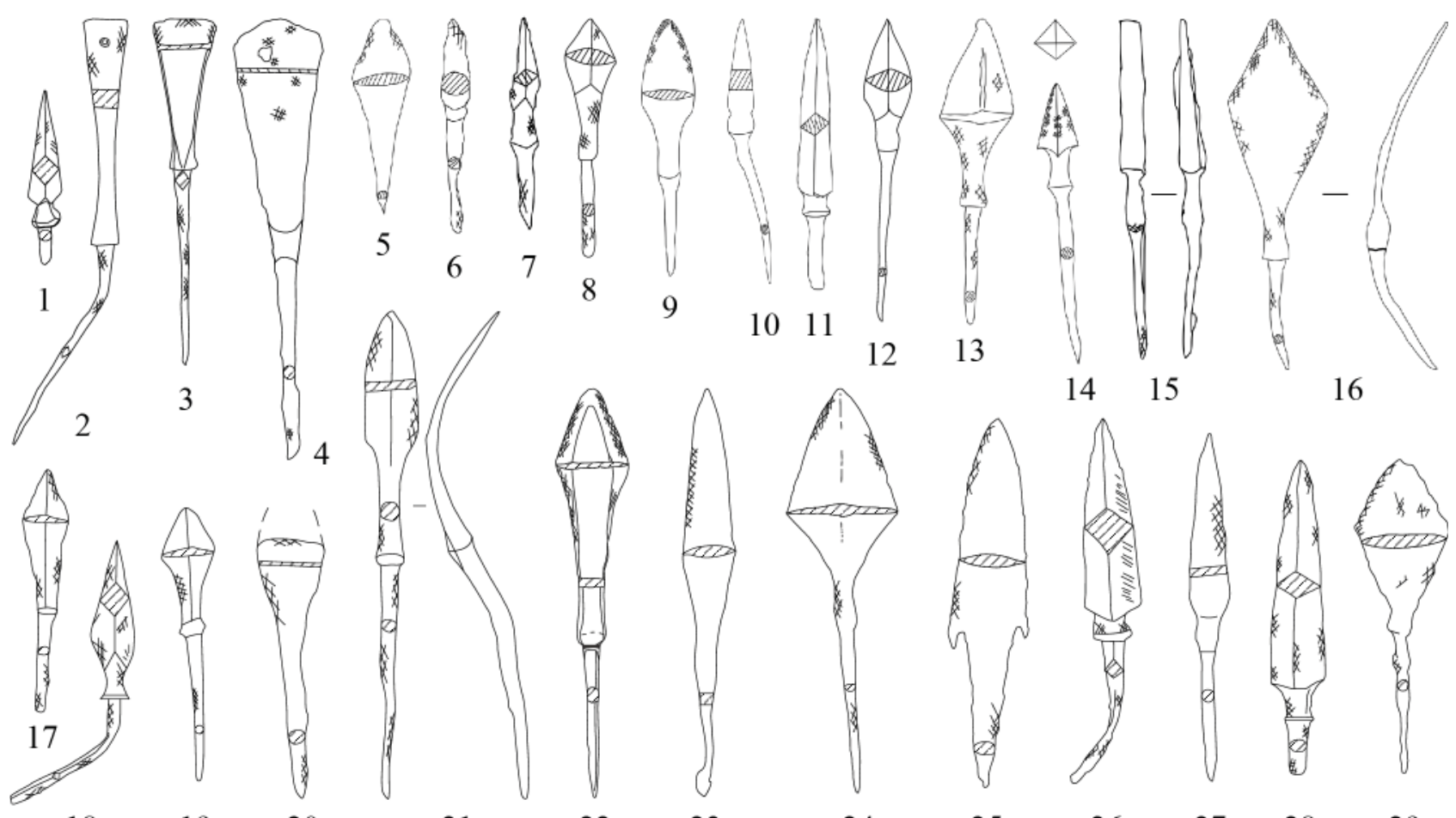

14
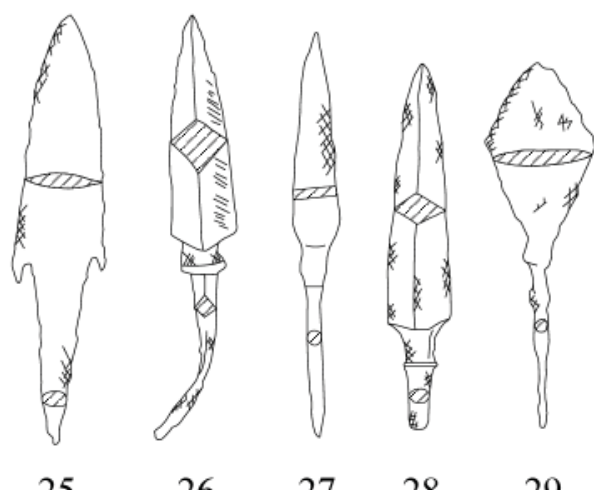

24

25

26

$27 \quad 28$

29

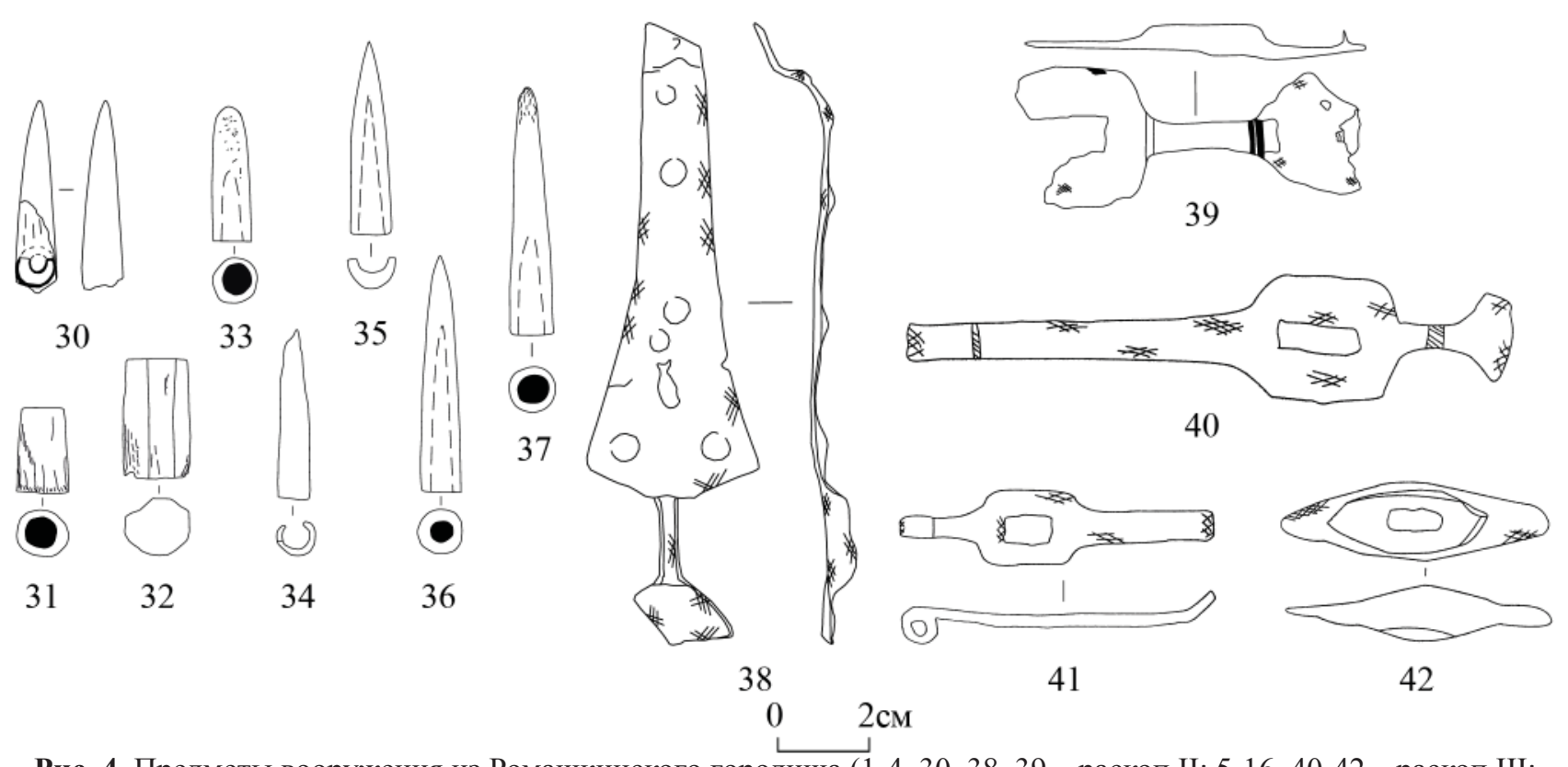

Рис. 4. Предметы вооружения из Ромашкинского городища (1-4, 30, 38, 39 - раскоп II; 5-16, 40-42 - раскоп III; 17-29, 31-37 - раскоп IV); (1-29, 38-42 - железо, 30-37 - кость)

Fig. 4. Weapons from Romashkino hillfort (1-4, 30, 38, 39 - excavation II; 5-16, 40-42 - excavation III; 17-29, 31-37 - excavation IV); (1-29, 38-42 - iron, 30-37 - bone)

бочонковидная высокая горловина (H3 у горшков - 4-7 см, у мисок - 3-5 см; D3 у горшков - 8-20 см, мисок - 12-22 см);

скошенный во внутрь венчик, у которого наружный край выступает на 0,1-0,2 см;

наличие богатой орнаментации верхней части посуды.

Характерный орнамент для ранней посуды - многорядный (обычно 7, иногда 5-6 рядов) веревочный штамп по горловине. Витая веревка шириной около 3 мм продавливалась в глину неглубоко, не наблюдается и строгая спаренность рядов. Направление вдавления в большинстве случаев в одну сторону. Плечик сосуда украшен мелкозубчатым гребенчатым штампом в виде правильной или перевернутой “елочки”, состоящей из 4-6 рядов. Мелкозубчатым гребенчатым узором украшен и внутренний скошенный край венчика. Такая характеристика присуща для керамики VII 


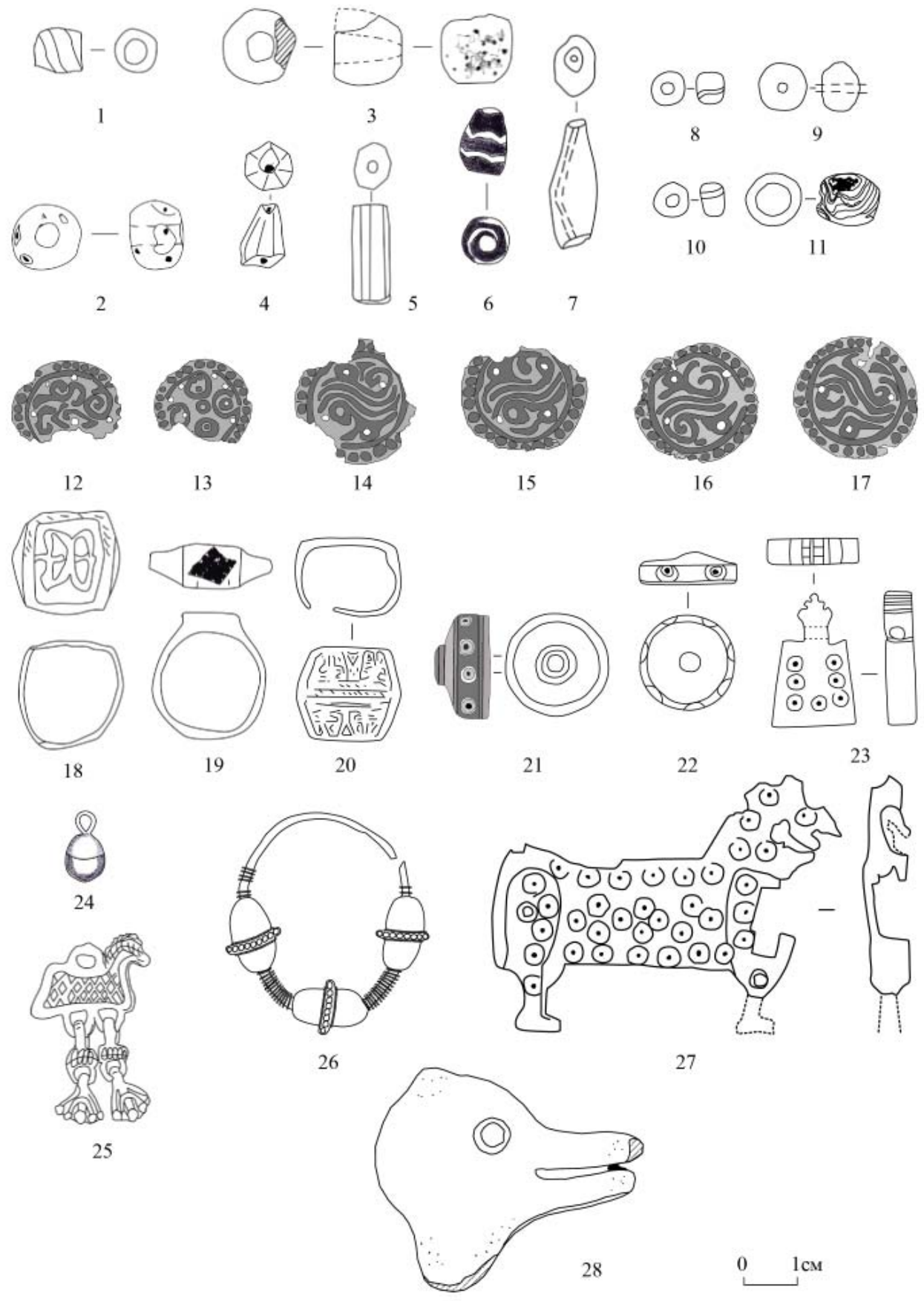

Рис. 5. Украшения из Ромашкинского городища (28 - раскоп II; 1-7, 18, 19, 24, 25 - раскоп III; 8-17, 20-23, 26, 27 - раскоп IV); (1, 3, 6, 8-11 - стекло; 2 - гашир; 4, 5, 7 - сердолик; 12-20, 24 - медь; 21-23 - кость; 2 5,26 - серебро; 27 - бронза; 28 - глина, полива)

Fig. 5. Ornamentation from Romashkino hillfort (28 - excavation II; 1-7, 18, 19, 24, 25 - excavation III; 8-17, 20-23, 26, 27 - excavation IV); (1, 3, 6, 8-11 - glass; 2 - hashir; 4, 5, 7 - carnelian; 12-20, 24 - copper; 21-23 - bone; 25,26 - silver; 27 - bronze; 28 - clay, glazing)

группы, бытовавшей с середины X до середины XI в.

Для посуды середины XI - XII вв. более характерны следующие признаки:

уменьшение доли раковинной примеси в тесте, встречается посуда с выщелоченной ракушкой;

обжиг более ровный;

некоторое увеличение толщины стенок сосудов; цилиндрическая горловина, реже встречаются в виде усеченного конуса и раструба (H3 у горшков - 3-5 см, у мисок - 2,8-3,5 cм; D3 у горшков - 9-22 см, мисок - 8-20 см);

скошенный вовнутрь венчик, наружу выступает на 0,05-0,1 см или вообще не выступает;

обеднение орнаментации и небрежность в технике ее нанесения. 
В связи с уменьшением высоты горловины сосудов сокращается до 4 количество рядов веревочного орнамента по горловине. При этом рисунок орнамента отпечатывался неравномерно в связи его нанесением на лучше просушенную керамику. В ямных конструкциях крупных размеров (ямы-кладовки, подпольные и хозяйственные ямы) постпетрогром всегда больше представлен в нижних отложениях. По мере заполнения ямы доля керамики VII группы уменьшается, но в то же время появляется посуда VIII группы (рис. 3: 11-14).

На сегодняшний день в материалах Староромашкинского комплекса, функционировавшего только в домонгольский период, представлено 89 фрагментов от 15 сосудов керамики VIII группы. Следует сказать, что в Прикамье нет памятника, где присутствует VIII группа в отсутствии VII группы. В Предкамье восточнее р. Шумбут она вообще не представлена (Нигамаев, 2005). Эта керамика сделана из песочного теста, иногда с добавлением раковины или шамота. По плечикам вместо гребенчатого штампа резные линии.

Логично представить XVII группу как результат дальнейшего развития VIII группы, когда ручная лепка уступает место гончарному производству (рис. 3: 17). Сам переход к использованию гончарного круга именно носителей “традиции” изготовления VIII группы керамики в закамских памятниках объясняется тем фактом, что керамики XVII группы там встречается в 1,5-2 раза больше. В раскопах Староромашкинского городища обнаружено 164 фрагмента от 28 сосудов керамики XVII группы.

Одной из проблем, разрешенных в последнее время в результате раскопок в прикамских городах, является вопрос о времени появления на Нижней Каме верхнекамского населения, связанного с родановской культурой. Это население оставило лепную посуду черного, бурого, серого оттенков с большим содержанием в тесте толченой раковины и украшенную гребенчатом штампом (рис. 3: 18). Ее, представленную горшковидными, чашевидными и котловидными круглодонными с приуплощенностью сосудами, Т.А. Хлебникова выделила в XVIII группу своей классификации и датировала золотоордынским периодом (Хлебникова, 1988). Больше всего она представлена в домонгольском слое посада Алабуги, меньше в Кирменском городище. В незначительном количестве керамика XVIII группы встречается в комплексе посуды Староромашкинского городища, который погиб в 1236 г. и больше не восстанавливался (Нигамаев, 2015, с. 37). Можно считать, что верхнекамское население в своем движении вниз по Каме в начале XIII в. достигло центральных районов Волжской Болгарии.

Предметы вооружения. В староромашкинских коллекциях представлены оружие ближнего и дальнего боя, их отдельные элементы, а также защитные средства (рис 4). Больше всего здесь обнаружено метательного оружия в виде различных типов железных и костяных наконечников стрел, спусковой детали арбалета-самострела, а меньше - предметов, относящихся к оружию ближнего боя и защитному снаряжению - гарды, пластины от доспехов, кольчужные кольца и т. д.

Наконечники стрел из памятника относятся к 11 типам, но особый интерес представляют наконечники типа 67 по классификации А.Ф. Медведева (1966, с. 53). Датируется данный тип на памятниках Восточной Европы XIII-XIV вв. На памятниках Центральной Азии такие наконечники встречаются раньше. Примечательно, что оба наконечника торчали на обгоревших остатках жилища № 1 (Нигамаев, 2015, с. 37).

Украшения. Украшения из памятника представлены сердоликовыми и стеклянными бусами, медными перстнями с орнаментом на щитке, серебряным височным кольцом с тремя бусами-желудями, птицевидными подвесками из оловянистой бронзы, медными шаровидными пуговицами, различными костяными поделками с солярным орнаментом, в том числе подвески-амулеты и т. д. (рис. 5). Серебряное височное кольцо относится группе 1 подгруппе Б виду 2 . Изделие весит 8,9 г, диаметр кольца 3,6 см. Традиция закреплять две половинки «желудей» с помощью обойм или сканной проволоки, как на данном изделии, относится ко второй половине домонгольского периода.

Староромашкинский комплекс, будучи памятником только домонгольской эпохи, интересен для дальнейшего изучения. В материальной культуре его населения, в частности в керамической посуде, присутствуют своеобразные черты, чего нет в других домонгольских памятниках. Они могут внести определенную ясность в этнокультурные процессы, происходящие в данном регионе. Надо отметить, что исследование одного из трех огромных посадов комплекса только начаты, а домонгольские могильники пока вообще не оконтурены. И наконец, нужно найти поселение золотоордынского могильника “Ташбилге”. 


\section{ЛИТЕРАТУРА}

Археологические памятники Центрального Закамья / Отв. ред. А.Х. Халиков. Казань: ИЯЛИ КФАН CCCP, $1988.98 \mathrm{c}$.

Булич А.К. Булгарские городища в Чистопольском кантоне ТАССР // ВНОТ. 1926. № 4. С. 76-80.

Медведев А.Ф. Ручное метательное оружие. Лук и стрелы. Самострел VIII - XIV вв. / САИ. Вып. E1-36. М.: Наука. 1966. 184 с.

Набиуллин Н.Г. Отчет об охранно-спасательных археологических исследованиях городища «Калюш» (Старо-Ромашкинское) на территории Чистопольского муниципального района Республики Татарстан в 2008 г. Казань, 2010. 18 с. 27 илл.

Нигамаев А.З. Болгарские города Предкамья: Алабуга, Кирмень, Чаллы: Своеобразие материальной культуры населения. Казань: Изд-во Казанск. ун-та, 2005. 228 с.

Нигамаев А.3. Археологические работы на Староромашкинском городище в 2013 году // В мире научных открытий. 2015. №11(71). С. 33-39.

Руденко К.A. Отчет о разведках в Чистопольском р-не Татарской АССР в 1989 г. Казань, 1990 / Архив ИА РАН, № 12730. Л.11.

Руденко К.A. Железные наконечники стрел VIII-XV вв. из Волжской Булгарии. Казань: Заман, 2003. $512 \mathrm{c}$.

Фахрутдинов Р.Г. Археологические памятники Волжско-Камской Булгарии и ее территория. Казань: Татар. кн. изд-во, 1975. 220 с. С.142; № 1137.

Хлебникова T.А. Гончарное производство Волжских Болгар X - начала ХІІІ вв. // Труды Куйбышевской археологической экспедиции. Т. 4 / МИА. № 111 / Отв. ред. А.П. Смирнов. М.: Изд-во Академии наук СССР, 1962. С. 93-152.

Хлебникова T.А. Керамика памятников Волжской Болгарии. К вопросу об этнокультурном составе населения. М.: Наука, 1984. 241 с.

Хлебникова T.A. Неполивная керамика Болгара // Город Болгар: Очерки ремесленной деятельности / Отв. ред. Г.А. Федоров-Давыдов. М.: Наука. 1988. С. 7-102.

\section{Информация об авторе:}

Нигамаев Альберт Зуфарович, кандидат исторических наук, доцент, Елабужский институт Казанского (Приволжского) федерального университета (г. Елабуга, Россия); доцент, Набережночелнинский педагогический университет (г. Набережные Челны, Россия); alnig.07@mail.ru

\section{REFERENCES}

Khalikov, A. Kh (ed.). 1988. Arkheologicheskie pamiatniki Tsentral'nogo Zakam'ia (Archaeological Monuments of the Central Trans-Kama Region). Kazan: Institute of Language, Literature and History, Kazan Branch of the USSR Academy of Sciences (in Russian).

Bulich, A. K. 1926. In Vestnik nauchnogo obshchestva tatarovedeniia (Bulletin of the Scientific Society for Tatar Studies). 4, (in Russian).

Medvedev, A. F. 1966. Ruchnoe metatel'noe oruzhie (luk i strely, samostrel) VIII-XIV vv. (Hand Missile Weapons (Bow and Arrows, Crossbow) of $8^{\text {th }}-14^{\text {th }}$ Centuries). Svod Arkheologicheskikh Istochnikov (Corpus of Archaeological Sources) E1-36. Moscow: "Nauka" Publ. (in Russian).

Nabiullin, N. G. 2010. Otchet ob okhranno-spasatel'nykh arkheologicheskikh issledovaniiakh gorodishcha «Kaliush» (Staro-Romashkinskoe) na territorii Chistopol'skogo municipal'nogo raiona Respubliki Tatarstan $v 2008$ g. ((Report on Security and Rescue Archaeological Studies at Kalyush (Staroe Romashkino) Hillfort in Chistopolsky Municipal District of the Republic of Tatarstan in 2008). Kazan (in Russian).

Nigamaev, A. Z. 2005. Bolgarskie goroda Predkam 'ia: Alabuga, Kirmen', Chally. Svoeobrazie material'noi kul'tury i naseleniia (Bolgar Towns of the Cis-Kama area: Alabuga, Kirmen, Chally. Originality of Material Culture and Population). Kazan: Kazan State University (in Russian).

Nigamaev, A. Z. 2015. In V mire nauchnykh otkrytii (In the World of Scientific Discoveries) 71 (11), (in Russian).

Rudenko, K. A. 1990. Otchet o razvedkakh v Chistopol'skom raione Tatarskoi ASSR v 1989 g. (Report on Explorations in Chistopolsky District of the Tatar ASSR in 1989). Archive of the Institute of Archaeology of the Russian Academy of Sciences, dossier 12730, P. 11 (in Russian).

Rudenko, K. A. 2003. Zheleznye nakonechniki strel VIII-XV vv. iz Volzhskoi Bulgarii. Issledovanie $i$ katalog (Iron Arrowheads of the $8^{\text {th }}-15^{\text {th }}$ Centuries from the Volga Bulgaria. Studies and Catalogue). Kazan: "Zaman" Publ. (in Russian). 
Fakhrutdinov, R. G. 1975. Arkheologicheskie pamiatniki Volzhsko-Kamskoi Bulgarii $i$ ee territoriia (Archaeological Sites of Volga-Kama Bulgaria and its Territory). Kazan: "Tatarskoe knizhnoe izdatel'stvo" Publ. (in Russian).

Khlebnikova, T. A. 1962. In Smirnov, A. P. (ed.). Trudy Kuybyshevskoi arkheologicheskoi ekspeditsii (Proceedings of the Kuybyshev Archaeological Expedition) 4. Materialy i issledovaniia po arkheologii SSSR (Materials and Studies in the USSR Archaeology) 111. Moscow: Academy of Sciences of the USSR, 93-152 (in Russian).

Khlebnikova, T. A. 1984. Keramika pamiatnikov Volzhskoi Bolgarii: (K voprosu ob etnokul'turnom sostave naseleniia) (Ceramic Ware of the Volga Bolgaria Sites. On the Issue of Ethnic and Cultural Composition of the Population). Moscow: "Nauka" Publ. (in Russian).

Khlebnikova, T. A. 1988. In Fedorov-Davydov, G. A. (ed.). Gorod Bolgar. Ocherki remeslennoi deiatel'nosti (Town of Bolgar. Essays on Handicrafts). Moscow: "Nauka" Publ., 7-102. (in Russian).

\section{About the Author:}

Nigamaev Albert Z. Candidate of Historical Sciences. Elabuga Institute of Kazan (Volga Region) Federal University. Kazanskaya St., 89, Elabuga, 423604, the Republic of Tatarstan; Naberezhnye Chelny State Pedagogical University, Nizametdinova st., 28, Naberezhnye Chelny, 423806, Republic of Tatarstan, Russian Federation; alnig.07@mail.ru

Статья поступила в журнал 01.04.2021 г. Статья принята к публикации 01.04.2021 г. 